\title{
PREVALENSI TINGKAT KECEMASAN REMAJA DI PANTI ASUHAN WISMA ANAK-ANAK HARAPAN DALUNG BALI TAHUN 2015
}

\author{
Ni Putu Suntiawati ${ }^{1}$, Wayan Westa ${ }^{2}$ \\ Program Studi Pendidikan Dokter, Fakultas Kedokteran Universitas Udayana ${ }^{1}$ \\ Bagian/SMF IImu Psikiatri FK Universitas Udayana/RSUP Sanglah ${ }^{2}$ \\ putusuntiawati@gmail.com
}

\begin{abstract}
ABSTRAK
Kecemasan adalah suatu keadaan patologis yang ditandai oleh perasaan ketakutan disertai tanda somatik pertanda sistem saraf otonom yang hiperaktif (Kaplan dan Saddock, 1997). Kecemasan dan ketakutan memiliki komponen fisiologis yang sama tetapi kecemasan tidak sama dengan ketakutan. Penyebab kecemasan berasal dari dalam dan sumbernya sebagian besar tidak diketahui sedangkan ketakutan merupakan respon emosional terhadap ancaman atau bahaya yang sumbernya biasanya dari luar yang dihadapi secara sadar. (Maramis,2005) Penelitian ini merupakan penelitian deskriptif analitik dengan pendekatan secara cross sectional. Penelitian ini dilaksanakan di Panti Asuhan Wisma Anak-Anak Harapan Dalung. Teknik sampling yang digunakan dalam penelitian ini adalah purposive random sampling. Dalam penelitian ini yang dipilih sebagai subjek penelitian hanya remaja putri dan remaja putra usia 13-25 tahun sebanyak 30 orang. Pengumpulan data dilakukan dengan wawancara satu persatu seluruh responden dengan mengunakan HARS untuk mengetahui angka kecemasan. Hasi dari penelitian ini didapatkan angka tertinggi kecemasan pada responden putra adalah pada kecemasan sedang sebanyak $56,3 \%$. Sedangkan angka tertinggi kecemasan pada responden putri adalah pada kecemasan ringan sebanyak $57,1 \%$. Selain itu, dari data tersebut juga dapat dilihat adanya kecemasan sangat berat pada 7,1\% responden putri. Berdasarkan usia responden dengan tingkat kecemasan didapatkan hasil angka tertinggi 33,3\% dari seluruh responden mengalami kecemasan ringan dan angka terendah 3,3\% dari seluruh responden mengalami kecemasan sangat berat. Sebanyak $46,2 \%$ dari responden yang mengalami kecemasan ringan merupakan responden yang berusia 13-15 tahun. Sedangkan angka 3,3\% dari responden yang mengalami kecemasan sangat berat merupakan responden usia 16-20 tahun.
\end{abstract}

Kata Kunci: kecemasan, panti asuhan, remaja, prevalensi

\section{PREVALENCE OF TEENAGER'S ANXIETY LEVEL IN WISMA ANAK-ANAK HARAPAN DALUNG ORPHANAGE 2015}

\section{ABSTRACT}

Anxiety is a pathologic conditions that is characterized by fear and somatic symptoms which is the sign of hyperactivity of autonomic neuron. (Kaplan dan Saddock, 1997) Anxiety and fear have the same physiology components, but anxiety is different from fear. The etiology of anxiety comes from the inside and most of the source is unknown and fear is an emotional response for threat or danger which is from the outside that be faced consciously. (Maramis,2005) This study is a descriptive analytic that is a cross sectional study. The study take place in Wisma Anak-Anak Harapan Dalung orphanage. This study use a purposive random sampling. The sample was 30 teenagers in age 13-25 years old. Data obtained by interviewing the respondents one by one using HARS to know the anxiety's level. The results obtained are the highest number in boys were found in medium anxiety which is $56,3 \%$. The highest number for girls were found in light anxiety which is $57,1 \%$. Besides that, data obtained there was $7,1 \%$ girls in very severe anxiety. Based on the age, data obtained was 33,3\% from all of the respondents have light anxiety and 3,3\% respondents have very severe anxiety. There were $46,2 \%$ respondents that had light anxiety was respondents in age $13-$ 15 years old. Numbers 3,3\% respondents that had very severe anxiety was respondents in age 16-20 years old. 
Keywords: anxiety, orphanage, teenager, prevalence

\section{PENDAHULUAN}

\section{Latar belakang}

Pada penelitian dari Ahmad et al. ditemukan bahwa anak yatim lebih mungkin merasa cemas, depresi, memperlihatkan kemarahan, menunjukan perasaan hilang harapan yang tinggi secara signifikan dan ide bunuh diri. Penelitian mengindikasikan bahwa onset depresi terjadi pada awal kehidupan sekarang ini dibandingkan dengan dekade sebelumnya. (Fawzy N, 2010)

Pengasuhan yang buruk, kurangnya stimulasi dan ketidakhadiran pengasuh tetap terlibat pada akibat negatif terhadap anak, penempatan di panti asuhan membuat anak-anak pada peningkatan resiko terhadap penyakit infeksi dan keterlambatan perkembangan bahasa. Pada awal masa kanak-kanak, kelembagaan meningkatkan kemungkinan yang menghilangkan mutu anak dan akan tumbuh menjadi orang dewasa yang mengalami gangguan mental dan tidak produktif secara ekonomi. Gangguan kesehatan mental berlanjut meningkat dalam panti asuhan, meskipun pada anak adopsi secara internasional, yang sebelumnya pernah tinggal di panti asuhan. Kemungkinan memiliki gangguan perkembangan dan kesehatan mental lebih besar, paling tidak pada jangka pendek maupun menengah, jika dibandingakan dengan yang sebelumnya ada di asuhan keluarga. (Fawzy N, 2010)

Anak yatim ditandai dengan tingginya tingkat kecemasan umum dan kecemasan sosial. Di lain pihak, mereka sering mencari perhatian dan pengakuan dari orang dewasa, mereka lebih cemas daripada orang seumur mereka yang tinggal dengan keluarganya mengenai kesan yang mereka buat pada orang lain. Mereka takut mendapatkan penilaian negatif. (Avakyan T, 2014)

Tinggal di panti asuhan akan menurunkan kemampuan anak yatim untuk beradaptasi dan berinteraksi dengan dunia dan orang lain. Penurunan strategi perilaku yang membantu adaptasi dapat menjadi kecemasan sosial pada anak-anak panti asuhan. (Avakyan T, 2014)

Konsekuensi dari kecemasan sosial pada anak yatim dapat menjadi lebih sulit beradaptasi dibandingkan dengan anak yang bukan yatim piatu karena struktur dari komunikasi sosial mereka. Kebutuhan terhadap pengakuan dan dukungan berlaku pada anak yatim piatu, menjadi motivasi utama mereka dalam berkomunikasi secara personal. (Avakyan T, 2014)

Stress pada awal kehidupan, seperti adopsi, perubahan pengasuh, atau pengalaman diabaikan secara emosional dapat mempengaruhi cara respon individu terhadap stimulus positif ataupun negatif. Respon yang berubah ini dapat timbul dari perubahan secara langsung dari bagaimana stimulus emosional dikodekan, dan/atau mengimplikasikan fungsi kognitif dalam modulasi emosi, seperti regulasi diri atau sifat menahan diri. Efek stres pada awal kehidupan ini telah diperiksa dalam tugas ataupun target penghargaan dan fungsi yang menghalangi. (Mueller S, 2012)

Stres pada awal kehidupan juga dialami ketika anak usia sekolah dan anak-anak diadopsikan oleh orang tua biologisnya atau dipisahkan dari pengasuh aslinya karena penganiayaan dan ditempatkan di tempat pengasuhan. Pengalaman dari tipe penganiayaan yang berbeda atau stres selama perubahan pengasuh yang kemungkinan mempengaruhi fungsi kognitif dan motivasional secara signifikan. Fungsi cognitif, di suatu sisi, termasuk proses berbeda seperti perhatian visual, peraturan kontrol diri, atau memori jangka pendek dan jangka panjang. Motivasi, di sisi lain, dapat didefinisikan sebagai simpanan energi untuk melengkapi sebuah aksi (atau fungsi kognitif). (Mueller S, 2012)

Sesuai dengan konteks dari penganiayaan dan stres awal, pengalaman negatif dengan pengasuh dapat mengubah sensitivitas terhadap insentif penghargaan dan hukuman. Seperti stres awal yang berhubungan dengan perubahan respon terhadap insentif dapat meningkatkan kerentanan psikopatologi. Selain itu, psikopatologi berhubungan dengan stres awal seperti gangguan mood dan kecemasan, yang ditentukan dengan kerusakan respon terhadap insentif. (Mueller S, 2012)

Situasi menakutkan termasuk berbicara di depan umum, bertemu dengan orang-orang baru, dan berbicara dengan figur yang berkuasa, adalah sedikit contoh. Gejala psikis dan motorik yang berhubungan dengan gangguan yang terjadi adalah wajah merona merah, gemetar, berkeringat, dan tidak dapat berkatakata, serta banyak individu dengan gangguan kecemasan sosial dengan gejala ketakutan diobservasi dengan yang lainnya. Sebagai hasilnya, paparan dengan situasi menakutkan biasanya disertai dengan 
antisipasi kecemasan, kesulitan, dan pengelakan. (Iverach L, 2014)

Adapun tujuan dari penelitian ini adalah untuk mengetahui adanya kecemasan pada remaja putra maupun remaja putri yang tinggal di panti asuhan, serta untuk mengetahui perbedaan derajat kecemasan antara remaja putra maupun remaja putri yang tinggal di panti asuhan.

Manfaat teoritis dari dilaksanakannya penelitian ini adalah dapat memperluas wawasan dan pengetahuan khususnya ilmu kedokteran jiwa, serta dapat memberikan data ilmiah mengenai gambaran tingkat kecemasan pada remaja putra dan putri yang tinggal di panti asuhan.

Manfaat praktis yang didapat pada penelitian ini diharapkan dapat menjadi masukan bagi pembimbing akademik mahasiswa, psikiater, psikolog, mahasiswa, pengelola panti asuhan dan berbagai pihak terkait lainnya guna membantu kelancaran dalam proses belajar mengajar mahasiswa dalam penyelesaian studi dan menjadi masukan serta pertimbangan bagi pengelola panti asuhan.

\section{METODE PENELITIAN}

\section{Rancangan Penelitian}

Penelitian ini merupakan penelitian deskriptif analitik dengan pendekatan secara cross sectional. Dalam penelitian Cross sectional digunakan pendekatan transversal, dimana observasi terhadap variabel bebas (faktor resiko) dan variabel terikat (efek) dilakukan hanya sekali pada saat yang sama.

\section{Tempat dan Waktu Penelitian}

Penelitian ini dilaksanakan di Panti Asuhan Wisma Anak-Anak Harapan Dalung. Pengumpulan data dimulai pada 14 Maret 2015 - 19 Maret 2015.

\section{Populasi Penelitian dan Sampel Penelitian}

Populasi dalam penelitian ini adalah remaja putri dan putra yang tinggal di Panti Asuhan Wisma Anak-Anak Harapan Dalung. Sampel dalam penelitian ini remaja putra dan putri yang tinggal di Panti Asuhan Wisma Anak-Anak Harapan Dalung. Remaja putra maupun putri yang dipilih adalah yang berusia 13-25 tahun yang tinggal di Panti Asuhan Wisma Anak-Anak Harapan Dalung. Dalam penelitian ini dipilih remaja putra dan putri sebanyak 30 orang.

\section{Teknik sampling}

Teknik sampling yang digunakan dalam penelitian ini adalah purposive random sampling. Purposive karena sampel dipilih berdasarkan pertimbangan tertentu (Sugiyono,2005). Dalam penelitian ini yang dipilih sebagai subjek penelitian hanya remaja putri dan remaja putra usia 13-25 tahun yang tinggal di Panti Asuhan Wisma Anak-Anak Harapan Dalung.

Setelah dilakukan pencuplikan dengan purposive sampling dilanjutkan dengan pencuplikan dengan metode random sampling. Pencuplikan random sederhana dilakukan terhadap remaja putri dan putra dimana masing-masing diambil 30 sampel secara acak sehingga masing-masing subjek atau unit populasi memiliki peluang yang sama dan independen untuk terpilih ke dalam sampel. (Murti,2006)

\section{Variabel Penelitian}

1. Variabel bebas: remaja putra dan putri usia $13-25$ tahun yang tinggal di Panti Asuhan Wisma AnakAnak Harapan Dalung.

2. Variabel terikat: kecemasan remaja putra dan putri usia 13-25 tahun yang tinggal di Panti Asuhan Wisma Anak-Anak Harapan Dalung.

3. Variabel luar:

Keadaan lain yang menyebabkan kecemasan adalah :

a. Kematian salah satu / semua anggota keluarga.

b. Perpisahan / perceraian orangtua.

c. Menderita sakit kronis.

Hal ini dapat diketahui dengan kuesioner stres psikososial modifikasi Harold and Ray.

\section{Definisi Operasional Variabel Penelitian}

1. Variabel bebas

a. Remaja putra usia 13-25 tahun yang tinggal di Panti Asuhan Wisma Anak-Anak Harapan Dalung

b. Remaja putri usia 13-25 tahun yang tinggal di Panti Asuhan Wisma Anak-Anak Harapan Dalung

2. Variabel terikat

a. Kecemasan: suatu keadaan patologis yang ditandai oleh perasaan ketakutan disertai tanda somatik pertanda sistem saraf otonom yang hiperaktif (Kaplan dan Saddock, 1997). Penentuan derajat kecemasan dengan cara menjumlah nilai skor pada skala HARS dan item 1-14 dengan hasil:

a. Skor kurang dari 14 = tidak ada kecemasan.

b. Skor $14-20=$ kecemasan ringan.

c. Skor $21-27=$ kecemasan sedang.

d. Skor 28-41 = kecemasan berat.

e. skor $42-56=$ kecemasan sangat berat

Desain Analisis Data 
Data yang diperoleh dari penelitian akan diuji dengan uji t. Uji-t digunakan untuk uji hipotesis dengan variable bebas nominal ( 2 nilai) dengan variable tergantung numerik. (Sastroasmoro Sudigdo, 2008) Analisis data akan dilakukan dengan menggunakan software SPSS windows versi 17.

\section{Instrumen Penelitian.}

Alat dan bahan penelitian :

1. Formulir biodata

3. Kuesioner HARS

\section{Cara Kerja dan Teknik Pengumpulan Data}

Pengumpulan data dilakukan dengan mengunjungi responden di Panti Asuhan Wisma Anak-Anak Harapan Dalung. Seluruh responden diwawancara satu persatu dengan mengunakan HARS untuk mengetahui angka kecemasan. Cara penilaian kecemasan adalah dengan memberikan nilai dengan kategori:

$0=$ Tidak ada gejala atau keluhan

$1=$ Gejala ringan

2 = Gejala sedang

$3=$ Gejala berat

$4=$ Gejala sangat berat

Penentuan derajat kecemasan dengan cara menjumlah nilai skor dan item 1-14 dengan hasil:

a. Skor kurang dari $14=$ tidak ada kecemasan.

b. Skor $14-20=$ kecemasan ringan.

c. Skor $21-27=$ kecemasan sedang.

d. Skor 28-41 = kecemasan berat.

e. skor $42-56=$ kecemasan sangat berat

Table 1. Distribusi tingkat kecemasan berdasarkan jenis kelamin

\begin{tabular}{|c|c|c|c|c|c|c|c|}
\hline & \multicolumn{5}{|c|}{ Kecemasan } & \multirow[b]{2}{*}{ Total } \\
\hline & & $\begin{array}{c}\text { Tidak Ada } \\
\text { Kecemasan }\end{array}$ & $\begin{array}{c}\text { Kecemasan } \\
\text { Ringan }\end{array}$ & $\begin{array}{c}\text { Kecemasan } \\
\text { Sedang }\end{array}$ & $\begin{array}{c}\text { Kecemasan } \\
\text { Berat }\end{array}$ & $\begin{array}{c}\text { Kecemasan } \\
\text { Sangat Berat }\end{array}$ & \\
\hline \multirow[t]{2}{*}{$\begin{array}{l}\text { Jenis_ } \\
\text { kelamin }\end{array}$} & Laki-laki & $\begin{array}{r}2 \\
12.5 \%\end{array}$ & $\begin{array}{r}2 \\
12.5 \%\end{array}$ & $\begin{array}{r}9 \\
56.3 \%\end{array}$ & $\begin{array}{r}3 \\
18.8 \%\end{array}$ & $\begin{array}{r}0 \\
.0 \%\end{array}$ & $\begin{array}{r}16 \\
100.0 \%\end{array}$ \\
\hline & Perempuan & $\begin{array}{r}4 \\
28.6 \%\end{array}$ & $\begin{array}{r}8 \\
57.1 \%\end{array}$ & $\begin{array}{r}0 \\
.0 \%\end{array}$ & $\begin{array}{r}1 \\
7.1 \%\end{array}$ & $\begin{array}{r}1 \\
7.1 \%\end{array}$ & $\begin{array}{r}14 \\
100.0 \%\end{array}$ \\
\hline Total & & $\begin{array}{r}6 \\
20.0 \%\end{array}$ & $\begin{array}{r}10 \\
33.3 \%\end{array}$ & $\begin{array}{r}9 \\
30.0 \%\end{array}$ & $\begin{array}{r}4 \\
13.3 \%\end{array}$ & $\begin{array}{r}1 \\
3.3 \%\end{array}$ & $\begin{array}{r}30 \\
100.0 \%\end{array}$ \\
\hline
\end{tabular}

Table 2. Distribusi tingkat kecemasan berdasarkan usia

\begin{tabular}{|c|c|c|c|c|c|c|c|}
\hline & \multicolumn{5}{|c|}{ Kecemasan } & \multirow[b]{2}{*}{ Total } \\
\hline & & $\begin{array}{l}\text { Tidak Ada } \\
\text { Kecemasan }\end{array}$ & $\begin{array}{c}\text { Kecemasan } \\
\text { Ringan }\end{array}$ & $\begin{array}{c}\text { Kecemasan } \\
\text { Sedang }\end{array}$ & $\begin{array}{c}\text { Kecemasan } \\
\text { Berat }\end{array}$ & $\begin{array}{l}\text { Kecemasan } \\
\text { Sangat Berat }\end{array}$ & \\
\hline \multirow[t]{6}{*}{ Usia } & $13-15$ th & & 6 & 5 & 1 & 0 & 13 \\
\hline & & $7.7 \%$ & $46.2 \%$ & $38.5 \%$ & $7.7 \%$ & $.0 \%$ & $100.0 \%$ \\
\hline & $16-20$ th & 3 & 2 & 2 & 0 & 1 & 8 \\
\hline & & $37.5 \%$ & $25.0 \%$ & $25.0 \%$ & $.0 \%$ & $12.5 \%$ & $100.0 \%$ \\
\hline & $21-25$ th & 2 & 2 & 2 & 3 & 0 & 9 \\
\hline & & $22.2 \%$ & $22.2 \%$ & $22.2 \%$ & $33.3 \%$ & $.0 \%$ & $100.0 \%$ \\
\hline \multirow{2}{*}{\multicolumn{2}{|c|}{ Total }} & 6 & 10 & 9 & 4 & 1 & 30 \\
\hline & & $20.0 \%$ & $33.3 \%$ & $30.0 \%$ & $13.3 \%$ & $3.3 \%$ & $100.0 \%$ \\
\hline
\end{tabular}


Wisma Anak-Anak Harapan Dalung yaitu sebanyak 30 orang. Dari total 30 orang responden yang ada merupakan gabungan dari remaja putra dan putri dengan jumlah 16 orang putra dan 14 orang putri.

Dari data tersebut didapatkan angka tertinggi kecemasan pada responden putra adalah pada kecemasan sedang sebanyak $56,3 \%$. Sedangkan angka tertinggi kecemasan pada responden putri adalah Dari data yang diperoleh berdasarkan usia responden dengan tingkat kecemasan didapatkan hasil angka tertinggi 33,3\% dari seluruh responden mengalami kecemasan ringan dan angka terendah $3,3 \%$ dari seluruh responden mengalami kecemasan sangat berat. Sebanyak $46,2 \%$ dari responden yang mengalami kecemasan ringan merupakan responden yang berusia 13-15 tahun. Sedangkan angka 3,3\% dari responden yang mengalami kecemasan sangat berat merupakan responden usia 16-20 tahun.

\section{PEMBAHASAN}

Berdasarkan hasil data responden menurut tingkat kecemasan dan jenis kelamin, sebanyak $56,3 \%$ responden laki-laki mengalami kecemasan sedang. Sedangkan pada responden perempuan sebanyak $57,1 \%$ mengalami kecemasan ringan. Anak yatim ditandai dengan tingginya tingkat kecemasan umum dan kecemasan sosial. Pada lain pihak, mereka mencari perhatian dan pengakuan dari orang dewasa, tetapi pihak lainnya, mereka lebih cemas daripada orang seumuran mereka yang tinggal dengan keluarganya mengenai kesan yang mereka buat pada orang lain. Mereka takut mendapatkan penilaian negative. (Avakyan T, 2014) terlebih dengan adanya $7,1 \%$ responden putri yang mengalami kecemasan sangat berat. Konsekuensi dari kecemasan sosial pada anak yatim dapat menjadi lebih sulit beradaptasi dibandingkan dengan anak yang bukan yatim piatu karena struktur dari komunikasi sosial mereka. Kebutuhan terhadap pengakuan dan dukungan berlaku pada anak yatim piatu, menjadi motivasi utama mereka dalam berkomunikasi secara personal. (Avakyan T, 2014)

Tingkat kecemasan responden pada penelitian ini berdasarkan usianya didapatkan 33,3\% dari seluruh responden mengalami kecemasan ringan. Sebanyak 46,2\% dari responden yang mengalami kecemasan ringan merupakan responden yang berusia 13-15 tahun. Angka 3,3\% responden yang mengalami kecemasan sangat berat merupakan responden usia 16-20 tahun.
Berdasarkan data yang terkumpul didapatkan tingkat kecemasan berbeda sesuai dengan jenis kelamin dari seluruh responden yang ada.

pada kecemasan ringan sebanyak 57,1\%. Selain itu, dari data tersebut juga dapat dilihat adanya kecemasan sangat berat pada $7,1 \%$ responden putri.

Dari hasil data yang telah didapatkan remaja yang tinggal dip anti asuhan cenderung mengalami kecemasan ringan. Sedangkan kecemasan sangat berat terjadi pada remaja pertengahan dengan rentang usia responden 16-20 tahun.

Kecemasan yang terjadi pada remaja yang tinggal di Panti Asuhan Wisma Anak-Anak Harapan Dalung ini masih merupakan kecemasan yang dapat ditangani oleh pribadi remaja sendiri yang lebih didominasi oleh kecemasan ringan. Sehingga dianggap tidak terlalu berpengaruh terhadap aktifitas maupun prestasi remaja yang tinggal di Panti Asuhan Wisma Anak-Anak Harapan Dalung ini.

\section{PENUTUP}

Kesimpulan

Dari penelitian mengenai gambaran kecemasan remaja di Panti Asuhan Wisma Anak-Anak Harapan Dalung tahun 2015 ini dapat disimpulkan bahwa berdasarkan jenis kelamin di dapatkan angka tertinggi 56,3\% pada kecemasan sedang pada responden putra dan angka tertinggi kecemasan $57,1 \%$ pada kecemasan ringan.

Berdasarkan usianya data yang didapatkan adalah 46,2\% dari responden yang mengalami kecemasan ringan merupakan responden yang berusia 13-15 tahun.

Sedangkan berdasarkan keseluruhan data didapatkan $33,3 \%$ dari total responden mengalami kecemasan ringan dan 3,3 \% dari total responden mengalami kecemasan sangat berat.

\section{Kelemahan penelitian}

Penelitian ini memiliki beberapa kekurangan, diantaranya: kurang terbukanya responden saat dilakukan wawancara menggunakan HARS, dan sample hanya diambil dari Panti Asuhan Wisma AnakAnak Harapan Dalung sehingga hasil penelitian merupakan gambaran khusus dari Panti Asuhan Wisma Anak-Anak Harapan Dalung saja.

Saran

Berdasarkan hasil penelitian ini, maka saran yang dapat disampaikan adalah perlunya perhatian 
khusus kepada remaja yang tinggal di panti asuhan terutama yang memiliki suatu kecemasan, sehingga dapat membantu mereka mengatasi masalah kecemasan tersebut agar dapat bersosialisasi dengan lebih baik.

\section{DAFTAR PUSTAKA}

1. Fawzy, Nagy and Fouad, Amira. Psychosocial and Developmental Status of Orphanage Children: Epidemiological Study. Department of Psychiatry Zagazig University. 2010.

2. Avakyan, Tamara V and Volikova, Svetlana V. Social Anxiety in Children. Psychology in Russia: State of the Art Volume 7, Issue 1. 2014.

3. Mueller, Sven $C$ et al. Incentive Effect on Inhibitory Control in Adolescentswith Early Life Stress: An Antisaccade Study. Child Abuse Negl. 2012.

4. Iverach, Lisa and Rapee, Ronald M. Social Anxiety Disorder and Stuttering: Current Status and Future Directions. Journal of Fluency Disorder 40. 2014.
5. Kaplan, H.I \& Saddock, B.J. Synopsis of Psychiatry. 7th ed. Lange Medical Publication Maruzen, Co. Ltd., 1997. pp: 777-817.

6. Maramis, W.F. Catatan IImu Kedokteran Jiwa. Surabaya: Airlangga University Press. 2005. pp:38, 107, 252-254.

7. Maslim, Rusdi. Panduan Praktis Penggunaan Klinis Obat Psikotropik (Psychotropic Medication). Jakarta. 2007.

8. Sugiyono. Statistika untuk Penelitian. Bandung: Alfabeta. 2005

9. Murti, B. Desain dan Ukuran Sample Penelitian Kuantitatif dan Kualitatif di Bidang Kesehatan. Yogyakarta: Gajah Mada University Press. 2006.

10. Sastroasmoro, Sudigdo dan Ismael, Sofyan. Dasardasar Metodologi Penelitian Klinis. Jakarta: Sagung Seto. 2008. 